Article

\title{
Anticancer Impact of Nitric Oxide (NO) and NO Combination with SMYD-3 Inhibitor on Breast Carcinomas
}

\author{
Jenna L. Gordon ${ }^{1}\left(\mathbb{0}\right.$, Kristin J. Hinsen ${ }^{2}$, Melissa M. Reynolds ${ }^{3, *}$ and Mark A. Brown ${ }^{4}$ \\ 1 Department of Chemistry, Colorado State University, Fort Collins, CO 80521, USA; jenna.short@colostate.edu \\ 2 Department of Biomedical Sciences, Colorado State University, Fort Collins, CO 80521, USA; \\ khinsen@rams.colostate.edu \\ 3 Department of Chemistry, Department of Chemical and Biological Engineering, School of Biomedical \\ Chemistry, Colorado State University, Fort Collins, CO 80523, USA \\ 4 Department of Clinical Sciences, Colorado State University, Fort Collins, CO 80521, USA; \\ mark.brown@colostate.edu \\ * Correspondence: melissa.reynolds@colostate.edu
}

Citation: Gordon, J.L.; Hinsen, K.J.; Reynolds, M.M.; Brown, M.A. Anticancer Impact of Nitric Oxide (NO) and NO Combination with SMYD-3 Inhibitor on Breast Carcinomas. Diseases 2021, 9, 82. https://doi.org/10.3390/ diseases 9040082

Academic Editor: Maurizio Battino

Received: 7 October 2021

Accepted: 9 November 2021

Published: 12 November 2021

Publisher's Note: MDPI stays neutral with regard to jurisdictional claims in published maps and institutional affiliations.

Copyright: (c) 2021 by the authors. Licensee MDPI, Basel, Switzerland. This article is an open access article distributed under the terms and conditions of the Creative Commons Attribution (CC BY) license (https:// creativecommons.org/licenses/by/ $4.0 /)$.

\begin{abstract}
Despite enormous advances in the detection and treatment of breast cancer, it still remains the leading cancer diagnosis and has the second highest mortality rate. Thus, breast cancer research is a high priority for academics and clinicians alike. Based on previous research indicating the potential of nitric oxide (NO) and SMYD-3 inhibition, this work sought to expand upon these concepts and combine the two approaches. Both NO (from S-Nitrosoglutathione (GSNO)), termed Group 1, and a combination therapeutic, inhibitor-4 (SMYD-3 inhibitor) plus NO (from GSNO), termed Group 2, were evaluated for their efficacy on breast carcinoma cell lines MCF7 and MDA-MB-231, and the normal MCF10A breast cell line, using cellular viability, colony formation capacity, cytotoxicity, and cellular apoptosis analysis. These results indicated that, in Group 1, breast carcinoma lines MCF7 and MDA-MB-231, cells experienced a moderate reduction in cellular viability ( $20-25 \%)$, a large reduction in colony formation capacity $(\sim 80-90 \%)$, a moderate increase in the relative number of dead cells, and a moderate increase in cellular apoptosis. Group 2 was significantly more impactful, with a $\sim 50 \%$ knockdown in cellular viability, a 100\% reduction in colony formation capacity, a large increase in the relative number of dead cells, and a large increase in cellular apoptosis. Additionally, Group 2 induced a very small impact on the normal MCF10A cell line. Cumulatively, this work revealed the exciting impact of this combination therapeutic, indicating its potential for clinical application and further research.
\end{abstract}

Keywords: breast cancer; nitric oxide; cell viability; colony formation; cytotoxicity; apoptosis

\section{Introduction}

Female breast cancer cases in the United States have been continually increasing over the past 20 years [1]. Fortunately, 5-year survival rates remain optimistic [2]. This is possible because of continued advancements in breast cancer detection and treatment options. In modern practice, the course of treatment is dependent upon three subcategories of breast cancer that are defined by the presence or absence of specific molecular markers for estrogen or progesterone receptors and human epidermal growth factor 2 (ERBB2; formerly HER2) [3,4]. Currently, chemotherapy, endocrine therapy, and ERBB2-targeted antibody or small molecule inhibitor therapy combined with chemotherapy are mainstays in breast cancer treatment [2,5-9]. Nevertheless, breast cancer far exceeds all other cancers in new cancer diagnoses and has the second highest mortality rate [1].

Enormous efforts are dedicated to developing new, effective therapeutic options for breast cancer. For example, several studies have highlighted the potential of nitric oxide (NO) [10-14]. However, the effect of nitric oxide on breast cancers is dichotomous: augmenting tumor growth and encouraging metastasis at low concentrations (nanomo- 
lar) $[11,15]$ while promoting tumor apoptosis and cytostasis at high concentrations (micromolar) [11-14]. The ability to cause site-specific delivery and control release kinetics limits its practical application. Thus, various NO-delivery platforms have been investigated, such as NONOates, $N$-diazeniumdiolates, and $S$-Nitrosothiols (RSNOs) [10-21]. RSNOs present two major advantages over other delivery platforms: they allow prolonged NO release and naturally exist in the body $[16,17,22]$.

Another therapeutic strategy focuses on SMYD (SET and MYND domain-containing) family proteins as molecular targets in cancer treatment [23-25]. In particular, SMYD3 is known to regulate cancer cell growth and proliferation $[23,24]$. Consequently, SMYD3 overexpression has been linked to increased proliferation, transformation, and metastasis of cancer cells [26,27]. Multiple studies highlight that when SMYD3 is inhibited, a substantial decrease in proliferative capacity of breast cell lines is observed [23,28,29].

Herein, the novel combination of NO, delivered via S-Nitrosoglutathione (GSNO) (Figure 1a), and SMYD3 inhibition, with inhibitor-4 (Figure 1b), is investigated for anticancer potential against breast cancers. In previous studies, the RSNO, GSNO, was shown to exhibit tumoricidal characteristics [30-32]. Likewise, a separate study indicated that a SYMD3 inhibitor, inhibitor-4, demonstrated potent impacts on two breast cancer lines, MCF7 and MDA-MB-231 (both lines linked to overexpression of SMYD3) [29]. By combining the two for a combination therapeutic, GSNO and inhibitor-4, we sought to surpass the efficacy of each individual therapeutic on MCF7 and MDA-MB-231 breast cancer lines.<smiles>NC(CCC(=O)NC(CSN=O)C(=O)NCC(=O)O)C(=O)O</smiles>

a

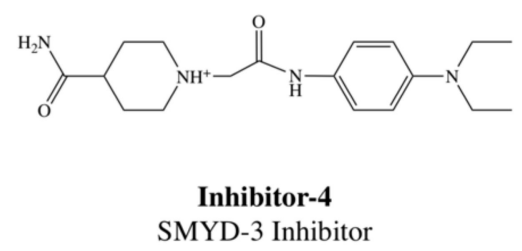

b

Figure 1. Structures of S-Nitrosoglutathione ((a) GSNO; NO-donor) and inhibitor-4 ((b) SMYD-3 inhibitor).

To evaluate and compare the efficacy of each individual therapeutic to the combination cocktail, cell viability, colony formation capacity, cytotoxicity, and cell apoptosis were examined. This manuscript contains the results pertaining to NO, delivered by $1 \mathrm{mM}$ GSNO, hereafter described as Group 1, and the combination therapeutic, SMYD3 inhibitor (200 $\mu \mathrm{M}$ inhibitor-4) and NO (from $1 \mathrm{mM}$ GSNO), hereafter described as Group 2. As previously mentioned, the findings pertaining to inhibitor-4 were investigated in a prior study [29]. Glutathione (GSH), the precursor to GSNO, was applied to cells as a functional control, highlighting NO as the active therapeutic (not GSNO). All of these results were considered in the final comparison.

\section{Experimental Section}

\subsection{Materials}

Dulbecco's Modified Eagle's Medium (DMEM), Eagle's Minimum Essential Medium (EMEM), F-12 Medium, Gibco Horse Serum (New Zealand origin), Invitrogen Cholera Toxin Subunit B (Recombinant), Alexa Fluor 488 Conjugate, Lonza Walkersville MEGM Mammary Epithelial Cell Growth Medium SingleQuots Supplements and Growth Factors (Insulin, BPE, Hydrocortisone), Promega Caspase-Glo $3 / 7$ Assay Kit, and PenicillinStreptomycin Solution were obtained from Fisher Scientific (Hampton, NH, USA). EquaFETAL 100\% Bovine Serum was purchased from Atlas Biologicals (Fort Collins, CO, USA). Reduced glutathione (GSH, High Purity), CellTiter-Blue Cell Viability Assay (CTB), and 3-(4,5-Dimethylthiazol-2-yl)-2,5-diphyltetrazolium bromide (MTT) were purchased from 
VWR International (Randor, PA, USA). Hydrochloric acid ( $\mathrm{HCl})$, EPA vials, Dead Cell Apoptosis Kit with Annexin V, FITC, and PI for flow cytometry, and Invitrogen ReadyProbes Cell Viability Imaging Kit were obtained from Thermo Fisher Scientific (Waltham, MA, USA). Dimethyl sulfoxide (DMSO) and Acetone ( $\geq 99.5 \%)$ were purchased from Sigma Aldrich (St. Louis, MO, USA). Sodium nitrate $\left(99.999 \% \mathrm{NaNO}_{2}\right.$ ) was obtained from Alfa Aesar (Ward Hill, MA, USA). Trypsin/EDTA solution was purchased from American Type Culture Collections (Manassas, VA, USA). The breast cancer cell lines MCF7 and MDA-MB-231, as well as the healthy breast epithelial cell line used, MCF10A, were provided purchased from American Type Culture Collection (ATCC). SMYD-3 inhibitor $\left(\mathrm{C}_{18} \mathrm{H}_{28} \mathrm{~N}_{4} \mathrm{O}_{2}\right)$, aka inhibitor-4, was purchased from Enamine (Kyiv, Ukraine).

\subsection{Synthesis of S-Nitrosoglutathione (GSNO)}

S-Nitrosoglutathione (GSNO) was synthesized through a previously developed method. In brief, sodium nitrite $\left(\mathrm{NaNO}_{2}\right)$ was added to a solution of reduced glutathione (GSH) in Millipore water and $2 \mathrm{M}$ hydrochloric acid $(\mathrm{HCl})$. The mixture was constantly stirred in an ice bath for $40 \mathrm{~min}$. The solution was treated with acetone, followed by an additional $10 \mathrm{~min}$ of stirring in the ice bath (mixture turned a red color). The red solution was filtered for $10 \mathrm{~min}$, first with gravity filtration for $10 \mathrm{~min}$ and then vacuum filtration for $3.5 \mathrm{~h}$. After the GSNO precipitate was isolated, it was washed successively with ice-water and acetone. The remaining red filtrate solution was discarded while the solid pink powder (GSNO) was retained. The precipitate was analyzed by UV-Vis spectrophotometry at $335 \mathrm{~nm}$ to confirm $<95$ purity.

\subsection{Cell Culture}

Complete cell media (complete DMEM/EMEM) for both breast cancer cell lines consisted of $500 \mathrm{~mL}$ of DMEM/EMEM cell media supplemented with $10 \%$ total volume fetal bovine serum and 1\% total volume penicillin-streptomycin. Complete cell media for healthy breast tissue cells, MCF10A, consisted of $500 \mathrm{~mL}$ of a 50/50 mixture of DMEM and F-12 media supplemented with $25 \mathrm{~mL}$ horse serum, $5 \mathrm{~mL}$ penicillin-streptomycin solution, $0.5 \mathrm{~mL}$ insulin, $2 \mathrm{~mL}$ BPE, $0.5 \mathrm{~mL}$ EGF, $0.5 \mathrm{~mL}$ hydrocortisone, and $50 \mu \mathrm{L}$ of $0.1 \mathrm{mg} / \mathrm{mL}$ stock of cholera toxin. Initially, $1 \mathrm{~mL}$ containing $10^{6}$ cells was thawed for 1-2 min in a $37{ }^{\circ} \mathrm{C}$ water bath, added to a $15 \mathrm{~mL}$ centrifuge tube containing $9 \mathrm{~mL}$ of pre-warmed complete media, and centrifuged for $5 \mathrm{~min}$ at $4{ }^{\circ} \mathrm{C}, 2000 \times g \mathrm{rpm}$. Then, the supernatant was aspirated, and the remaining pellet was resuspended in $5 \mathrm{~mL}$ of complete media. This was added to T-25 $\mathrm{cm}^{2}$ flasks containing $5 \mathrm{~mL}$ of complete media. Cultures were incubated at $37^{\circ} \mathrm{C}, 5 \% \mathrm{CO}_{2}$ for at least $48 \mathrm{~h}$ before fresh complete media was provided every 24-72 h. Macroscopic observation and cell counting via hemocytometer were used to count and split cell cultures.

\subsection{Cell Viability Assays}

\subsubsection{Experimental Setup}

In the cell viability assays, cells were plated at 100,000-200,000 cells/mL (MTT, CTB, respectively) for Group 1 and 500,000 cells/mL for Group 2 in $100 \mu \mathrm{L}$ increments in 96-well plates and incubated at $37^{\circ} \mathrm{C}, 5 \% \mathrm{CO}_{2}$. The media was aspirated and discarded after $24 \mathrm{~h}$. Group 1 positive control samples (PC; $\geq 4$ samples) received $100 \mu \mathrm{L}$ of complete media, samples received $100 \mu \mathrm{L}$ of $1 \mathrm{mM}$ GSNO (sample; $\geq 4$ samples), and the functional control samples (GSH; $\geq 4$ samples) received $100 \mu \mathrm{L}$ of $1 \mathrm{mM} \mathrm{GSH}$. The plate was incubated for $24 \mathrm{~h}$. Group 2 positive control samples (PC; $\geq 4$ samples) received $100 \mu \mathrm{L}$ of complete media that was replaced after $24 \mathrm{~h}$, samples received $100 \mu \mathrm{L}$ of $200 \mu \mathrm{M}$ inhibitor- 4 for $24 \mathrm{~h}$, followed by $24 \mathrm{~h}$ treatment with $100 \mu \mathrm{L}$ of $1 \mathrm{mM}$ GSNO (sample; $\geq 4$ samples), and the functional control samples (GSH; $\geq 4$ samples) received $100 \mu \mathrm{L}$ of $1 \mathrm{mM}$ GSH that was replaced with media after $24 \mathrm{~h}$. After another $24 \mathrm{~h}$ of incubation, on day 3 , the media was aspirated, and each well was given $100 \mu \mathrm{L}$ of complete media. The appropriate cell viability assay was then performed (Supplementary Materials, Excel File 3). 


\subsubsection{Assay Procedures \\ MTT Assays}

Following the outlined experimental setup, $10 \mu \mathrm{L}$ of $12 \mathrm{mM}$ MTT stock solution was added to each well. Plates were incubated for $3 \mathrm{~h}$. Then, $50 \mu \mathrm{L}$ of DMSO was added to each well. Plates were placed back in the incubator for $10 \mathrm{~min}$ to solubilize the MTT formazan. Finally, a microplate reader was used to measure absorbance values at $540 \mathrm{~nm}$.

\section{CTB Assays}

Subsequent to the experimental setup above, $20 \mu \mathrm{L}$ of CTB stock solution was added to each well. Then, plates were incubated for $3 \mathrm{~h}$. Finally, a microplate reader was used to measure absorbance values at $570 \mathrm{~nm}$ and $600 \mathrm{~nm}$.

In both assays, absorbance measurements were detected using a BioTek Synergy 2 MultiDetection Microplate Reader. Data points represent the mean \pm standard deviation (SD).

\subsection{Colony Formation Assays}

In the colony formation assays, cells were plated at 100,000 cells / $\mathrm{mL}$ (Group 1) and 500,000 cells $/ \mathrm{mL}$ (Group 2) in $1 \mathrm{~mL}$ increments in 24-well plates and then incubated at $37^{\circ} \mathrm{C}, 5 \% \mathrm{CO}_{2}$ for $24 \mathrm{~h}$ in 24 -well plates. The media was then aspirated from all wells and discarded. Group 1 positive control samples (PC; $\geq 4$ samples) received $1 \mathrm{~mL}$ of complete media, samples received $1 \mathrm{~mL}$ of $1 \mathrm{mM}$ GSNO (sample; $\geq 4$ samples), and the functional control samples (GSH; $\geq 4$ samples) received $1 \mathrm{~mL}$ of $1 \mathrm{mM} \mathrm{GSH}$. The plate was incubated for $24 \mathrm{~h}$. Group 2 positive control samples (PC; $\geq 4$ samples) received $1 \mathrm{~mL}$ of complete media that was replaced after $24 \mathrm{~h}$, samples received $1 \mathrm{~mL}$ of $200 \mu \mathrm{M}$ inhibitor-4 for $24 \mathrm{~h}$, followed by $24 \mathrm{~h}$ treatment with $1 \mathrm{~mL}$ of $1 \mathrm{mM}$ GSNO (sample; $\geq 4$ samples), and the functional control samples (GSH; $\geq 4$ samples) received $1 \mathrm{~mL}$ of $1 \mathrm{mM} \mathrm{GSH}$ that was replaced with media after $24 \mathrm{~h}$. After incubation, cells were harvested, counted, and then re-plated at 500 cells $/ \mathrm{mL}$ in new 24 -well plates. These plates were placed back into the incubator and observed every $24-72 \mathrm{~h}$ for up to three weeks via brightfield microscopy to determine the formation of colonies, defined as masses $\geq 50$ cells.

Colony formation images were captured using an Invitrogen Cytation 7 Fluorescence Microscope (Carlsbad, CA, USA). Data points represent the mean \pm standard deviation (SD).

\subsection{LIVE/DEAD Assays}

In the LIVE/DEAD assays, cells were plated at $100 \mu \mathrm{L}$ increments of 100,000 cells $/ \mathrm{mL}$ (Group 1) and 500,00 cells / $\mathrm{mL}$ (Group 2) in 96-well plates before $24 \mathrm{~h}$ of incubation at $37^{\circ} \mathrm{C}$, $5 \% \mathrm{CO}_{2}$. Group 1 positive control samples (PC; $\geq 4$ samples) received $100 \mu \mathrm{L}$ of complete media, samples received $100 \mu \mathrm{L}$ of $1 \mathrm{mM}$ GSNO (sample; $\geq 4$ samples), and the functional control samples (GSH; $\geq 4$ samples) received $100 \mu \mathrm{L}$ of $1 \mathrm{mM} \mathrm{GSH}$. The plate was incubated for $24 \mathrm{~h}$. Group 2 positive control samples (PC; $\geq 4$ samples) received $100 \mu \mathrm{L}$ of complete media that was replaced after $24 \mathrm{~h}$, samples received $100 \mu \mathrm{L}$ of $200 \mu \mathrm{M}$ inhibitor- 4 for $24 \mathrm{~h}$, followed by $24 \mathrm{~h}$ treatment with $100 \mu \mathrm{L}$ of $1 \mathrm{mM}$ GSNO (sample; $\geq 4$ samples), and the functional control samples (GSH; $\geq 4$ samples) received $100 \mu \mathrm{L}$ of $1 \mathrm{mM} \mathrm{GSH}$ that was replaced with media after $24 \mathrm{~h}$. Following another $24 \mathrm{~h}$ of incubation, 10 drops of both the Blue and Green ReadyProbes Cell Viability Imagine Kit stock solutions were added to $5 \mathrm{~mL}$ complete media. The media was aspirated from each well and $100 \mu \mathrm{L}$ of the Blue/Green stock solution was added to each well before it was again incubated for $15 \mathrm{~min}$. Imaging via fluorescent microscopy was used for qualitative comparison of the relative number of live cells versus dead cells in each well.

LIVE/DEAD images were captured using an Invitrogen Cytation 7 Fluorescence Microscope (Carlsbad, CA, USA). Live cells exhibited blue fluorescence while dead cells exhibited green fluorescence. 


\subsection{Cell Apoptosis Assays}

\subsubsection{Caspase-Glo 3/7 Apoptosis Assay}

In the Caspase-Glo 3/7 apoptosis assays, cells were plated at $100 \mu \mathrm{L}$ increments of 100,000 cells / mL (Group 1) and 500,000 cells/mL (Group 2) in 96-well plates before $24 \mathrm{~h}$ of incubation at $37{ }^{\circ} \mathrm{C}, 5 \% \mathrm{CO}_{2}$. Next, all of the media was aspirated and discarded before Group 1 positive control samples (PC; $\geq 4$ samples) received $100 \mu \mathrm{L}$ of complete media, samples received $100 \mu \mathrm{L}$ of $1 \mathrm{mM}$ GSNO (sample; $\geq 4$ samples), and the functional control samples (GSH; $\geq 4$ samples) received $100 \mu \mathrm{L}$ of $1 \mathrm{mM} \mathrm{GSH}$. The plate was incubated for $24 \mathrm{~h}$. Group 2 positive control samples (PC; $\geq 4$ samples) received $100 \mu \mathrm{L}$ of complete media that was replaced after $24 \mathrm{~h}$, samples received $100 \mu \mathrm{L}$ of $200 \mu \mathrm{M}$ inhibitor- 4 for $24 \mathrm{~h}$, followed by $24 \mathrm{~h}$ treatment with $100 \mu \mathrm{L}$ of $1 \mathrm{mM}$ GSNO (sample; $\geq 4$ samples), and the functional control samples (GSH; $\geq 4$ samples) received $100 \mu \mathrm{L}$ of $1 \mathrm{mM} \mathrm{GSH}$ that was replaced with media after $24 \mathrm{~h}$. Following another $24 \mathrm{~h}$ of incubation, all samples were given $100 \mu \mathrm{L}$ Caspase-Glo 3/7 Reagent. Plates were incubated at room temperature for $2.5 \mathrm{~h}$ before luminescence of all samples was measured with a BioTek Synergy 2 Multi-Detection Microplate Reader (Winooski, VT, USA). Data points represent the mean \pm standard deviation (SD).

\subsubsection{Annexin V/PI Apoptosis Assay}

In the AnnexinV/PI apoptosis assays, cells were plated at $100 \mu \mathrm{L}$ increments of 100,000 cells / $\mathrm{mL}$ (Group 1) and 500,000 cells/mL (Group 2) in 24-well plates before $24 \mathrm{~h}$ of incubation at $37{ }^{\circ} \mathrm{C}, 5 \% \mathrm{CO}_{2}$. Next, all of the media was aspirated and discarded before Group 1 positive control samples (PC; $\geq 4$ samples) received $100 \mu \mathrm{L}$ of complete media, samples received $100 \mu \mathrm{L}$ of $1 \mathrm{mM}$ GSNO (sample; $\geq 4$ samples), and the functional control samples (GSH; $\geq 4$ samples) received $100 \mu \mathrm{L}$ of $1 \mathrm{mM}$ GSH. The plate was incubated for $24 \mathrm{~h}$. Group 2 positive control samples (PC; $\geq 4$ samples) received $100 \mu \mathrm{L}$ of complete media that was replaced after $24 \mathrm{~h}$, samples received $100 \mu \mathrm{L}$ of $200 \mu \mathrm{M}$ inhibitor- 4 for $24 \mathrm{~h}$, followed by $24 \mathrm{~h}$ treatment with $100 \mu \mathrm{L}$ of $1 \mathrm{mM} \mathrm{GSNO}$ (sample; $\geq 4$ samples), and the functional control samples (GSH; $\geq 4$ samples) received $100 \mu \mathrm{L}$ of $1 \mathrm{mM} \mathrm{GSH}$ that was replaced with media after $24 \mathrm{~h}$. Following another $24 \mathrm{~h}$ of incubation, all samples were harvested, washed with phosphate-buffered saline (PBS), re-centrifuged, and resuspended in 1X annexin-binding buffer. Cells were re-plated at $100 \mu \mathrm{L}$ increments 1,000,000 cells $/ \mathrm{mL}$ in $24-$-well plates. All wells received $5 \mu \mathrm{L}$ FITC annexin V (Component A) and $1 \mu \mathrm{L}$ of $100 \mu \mathrm{g} / \mathrm{mL}$ PI solution. Plates were incubated at room temperature for $15 \mathrm{~min}$ before $400 \mu \mathrm{L}$ of annexin-binding buffer was added, mixed gently, and stored on ice. Cells were analyzed within $1 \mathrm{~h}$ by flow cytometry on a Cytek 4-laser Aurora instrument (Cytek, Fremont, CA, USA). A minimum of $3 \times 10^{4}$ events was collected from each sample. Multivariate data were analyzed with SpectroFlo software (Cytek, Fremont, CA, USA). APC Annexin V-/PI-, APC Annexin $\mathrm{V}-/ \mathrm{PI}+$, APC Annexin V+/PI-, APC or Annexin V+/PI+ represented viable, necrotic, early apoptotic, or late apoptotic cells, respectively.

\subsection{Data Analysis and Statistics}

All results were reported as an average and standard deviation with $n>5$ for each group. One way-ANOVA was used to perform all statistical analysis and $p<0.05,0.01$, $0.001(* * * * * *$, respectively) defined statistically significant differences.

\section{Results and Discussion}

The overall goal of this study was to determine the relative efficacy of NO, delivered by GSNO only (Group 1), and the combination therapeutic, SMYD-3 inhibitor (inhibitor-4) and NO from GSNO (Group 2) on human breast carcinomas MCF7 and MDA-MB-231. The impact of inhibitor-4 alone was assessed in a separate study conducted by our collaborators, Alshiraihi et al. [29]. Various methods were used to determine efficacy, including cell viability assays (MTT and CTB), colony formation assays, LIVE/DEAD cytotoxicity assays, and cell apoptosis assays (Caspase-Glo 3/7 and Annexin V/PI). Additionally, normal 
MCF10A breast cells were evaluated in an identical manner to gauge the discriminatory capabilities of these treatment groups. In all assays, the sample groups consisted of positive control (PC) cells, sample (S) cells (Group 1 or Group 2), and functional control (GSH) cells.

\subsection{Cell Viability Assays}

Initially, the effects of two treatment groups, Group 1 and Group 2, were assessed for their impact on viability of MCF7 and MDA-MB-231 cells compared to normal breast cells, MCF10A. Both MTT and CTB cell viability assays showed a significant decrease in viability after the $24 \mathrm{~h}$ treatment period for each treatment group. Unfortunately, normal MCF10A cells treated with $\mathrm{NO}$ also experienced a similar decrease in viability when treated with Group 1. Optimistically, when treated with Group 2, normal MCF10A cells did not experience a more significant drop in viability. Importantly, the decrease in viability due to Group 2 was $\sim 46-50 \%$, which was significantly more pronounced than the NO-only Group 1 or the inhibitor-4-only group [29]. These results suggest that Group 2 significantly reduces the viability of breast carcinomas while retaining normal cell health.

\subsubsection{MTT Assay}

Group 1

In Group 1, the MTT assay revealed a moderate decrease in MCF7, MDA-MB-231, and MCF10A cell viability (Figure 2). Explicitly, after the $24 \mathrm{~h}$ treatment period, the viability of MCF7, MDA-MB-231, and MCF10A S (NO-treated) cells was $82 \% \pm 7 \%, 77 \% \pm 4 \%$, and $85 \% \pm 6 \%$, respectively. The viability of GSH-treated cells remained unchanged. Collectively, these data illustrate the potential of NO in breast carcinoma treatment. However, these data also reveal that NO (Group 1) cannot act as a standalone treatment and that normal breast cells are impacted, necessitating additional investigation.

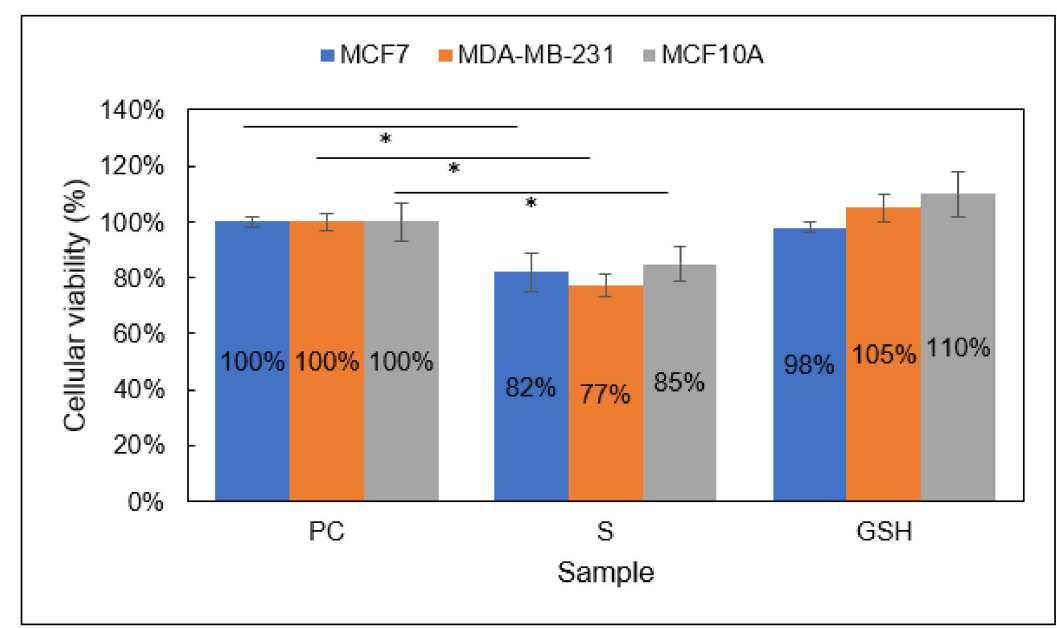

Figure 2. Cellular viability of MCF7 (blue), MDA-MB-231 (orange), and MCF10A (gray) cells analyzed with the MTT assay. Sample groups include: PC (untreated), S (Group 1), and GSH (functional control) cells. Data points represent the mean \pm standard deviation. Statistical differences from the positive control are signified by ${ }^{*} p<0.05$.

\section{Group 2}

MTT assay results showed Group 2-treated MCF7 and MDA-MB-231 breast carcinomas experienced a significant reduction in cellular viability after $24 \mathrm{~h}$ (Figure 3). MCF7 and MDA-MB-231 S (Group 2) cells showed $51 \% \pm 1 \%$ and $50 \% \pm 1 \%$ viability, respectively. Additionally, $85 \% \pm 2 \%$ of normal MCF10A cells retained viability after treatment. These data strongly indicate the increased efficacy of Group 2 on breast carcinomas versus NO (Group 1) alone or inhibitor-4 alone [29]. Individually, NO and inhibitor-4 alone reduced the cellular viability of both breast cancer lines by $\sim 20-25 \%$ each, so the cumulative decrease displayed here, $\sim 50 \%$, was expected. It was not clear whether normal cells would 
experience the same reduction in viability. Group 1 cells did experience a $\sim 15 \%$ reduction in viability when exposed to NO only (Figure 2). However, inhibitor-4-exposed cells did not experience a statistically significant reduction in viability. Fortunately, the Group 2 results indicated a similar, $\sim 15 \%$, reduction in viability to the Group 1 results.

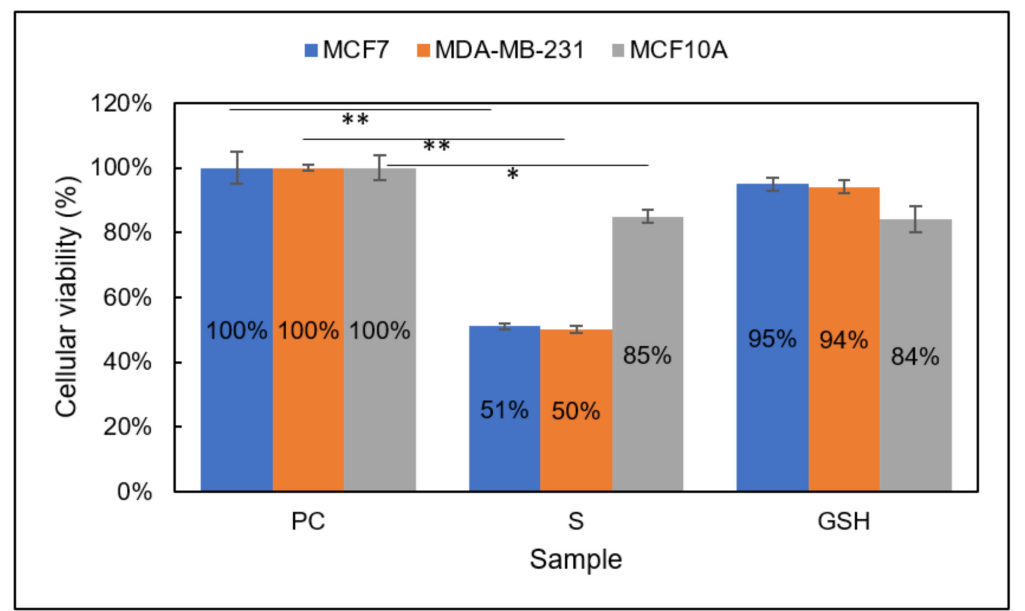

Figure 3. Cellular viability of MCF7 (blue), MDA-MB-231 (orange), and MCF10A (gray) cells analyzed using the MTT assay. Sample groups include: PC (untreated), S (Group 2), and GSH (functional control) cells. Data points represent the mean \pm standard deviation. Statistical differences from the positive control are denoted by ${ }^{*} p<0.05,{ }^{* *} p<0.01$.

\subsubsection{CTB Assay}

Group 1

Comparable to the MTT assay results, the CTB assay revealed a decrease in MCF7, MDA-MB-231, and MCF10A cell viability in Group 1 (Figure 4). After the treatment period, the CTB assay showed S viability of MCF7, MDA-MB-231, and MCF10A cells to be $76 \% \pm 8 \%, 82 \% \pm 7 \%$, and $80 \% \pm 5 \%$, respectively, after the $24 \mathrm{~h}$ treatment period. Again, these results echo those from the MTT assay results, showing a moderate decrease in viability of breast carcinomas as well as normal breast cells. Taken together, Group 1 does not show vast promise as a standalone treatment for breast carcinomas.

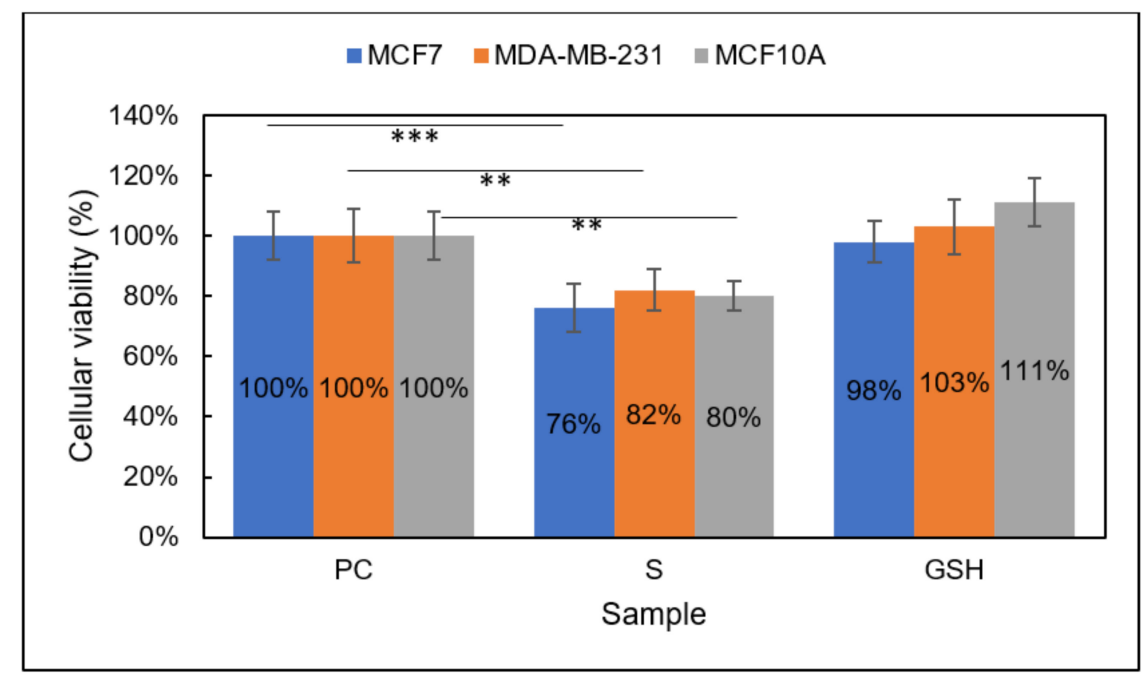

Figure 4. Cellular viability of MCF7 (blue), MDA-MB-231 (orange), and MCF10A (gray) cells analyzed using the CTB assay. Sample groups include: PC (untreated), S (Group 1), and GSH (functional control) cells analyzed using the CTB assay. Data points represent the mean \pm standard deviation. Statistical differences from the positive control are indicated by ${ }^{* *} p<0.01,{ }^{* * *} p<0.001$. 


\section{Group 2}

Again, the CTB assay results here reiterate those of the MTT assay above, indicating significant reduction in both breast carcinoma lines and preserving the viability of the normal breast line in Group 2 (Figure 5). After $24 \mathrm{~h}$ treatment with each therapeutic consecutively, the viability of MCF7 and MDA-MB-231 S cells was 56\% $\pm 5 \%$ and $54 \% \pm 6 \%$, respectively. The viability of normal MCF10A cells was $90 \pm 7 \%$. These data, along with the MTT data above, confirm the improved impact of Group 2 versus either therapeutic individually [29]. Collectively, the viability data collected prompted further investigation of the role of Group 1 and Group 2.

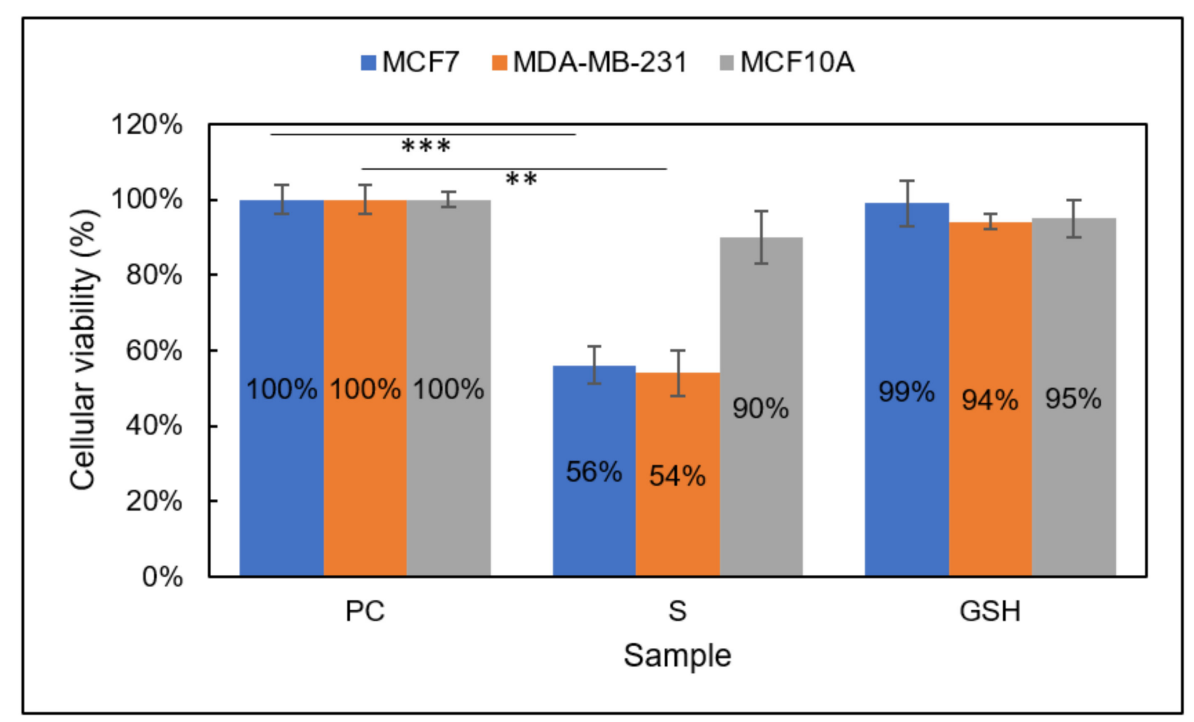

Figure 5. Cellular viability of MCF7 (blue), MDA-MB-231 (orange), and MCF10A (gray) cells analyzed using the CTB assay. Sample groups include: PC (untreated), S (Group 2), and GSH (functional control) cells analyzed with the CTB assay. Data points represent the mean \pm standard deviation. Statistical differences from the positive control are represented by ${ }^{* *} p<0.01,{ }^{* * *} p<0.001$.

\subsection{Colony Formation Assays}

Clonogenic capacity is an important indicator of therapeutic efficacy. As such, MCF7, MDA-MB-231, and MCF10A cells were allowed to form colonies after $24 \mathrm{~h}$ treatment with each of the two treatment groups, Group 1 and Group 2. Both treatment groups significantly reduced colony formation (defined as masses of $>50$ cells) in both breast cancers (MCF7 and MDA-MB-231). Unfortunately, both groups also significantly reduced colony formation in the normal MCF10A cell line. Colony formation was further reduced in Group 2, but only by a small margin. Additionally, colony formation was completely halted in Group 2 for both breast cancer cell lines. These results suggested a potential drawback in the conceivable application of each treatment option. However, further investigation was deserved.

Group 1

The colony formation capacity of both breast carcinoma lines, MCF7 and MDA-MB231 cells, and the normal breast cell line, MCF10A, was decreased significantly after $24 \mathrm{~h}$ in Group 1 (Figure 6). The number of colonies formed for MCF7 cells decreased from $20 \pm 2$ for untreated PC cells to $3 \pm 1$ for $S$ (Group 1) cells. Similarly, the number of colonies formed for MDA-MB-231 cells decreased from $27 \pm 2$ for untreated cells to $4 \pm 1$ for $S$ cells. Additionally, the number of colonies formed after NO-exposure (Group 1) for MCF10A cells was $5 \pm 2$ for $S$ cells versus $15 \pm 2$ for untreated PC cells. The reduction in colony formation capacity in the normal MCF10A line presented a potential drawback to this therapeutic approach. Thus, other indicators of therapeutic efficacy were explored. 


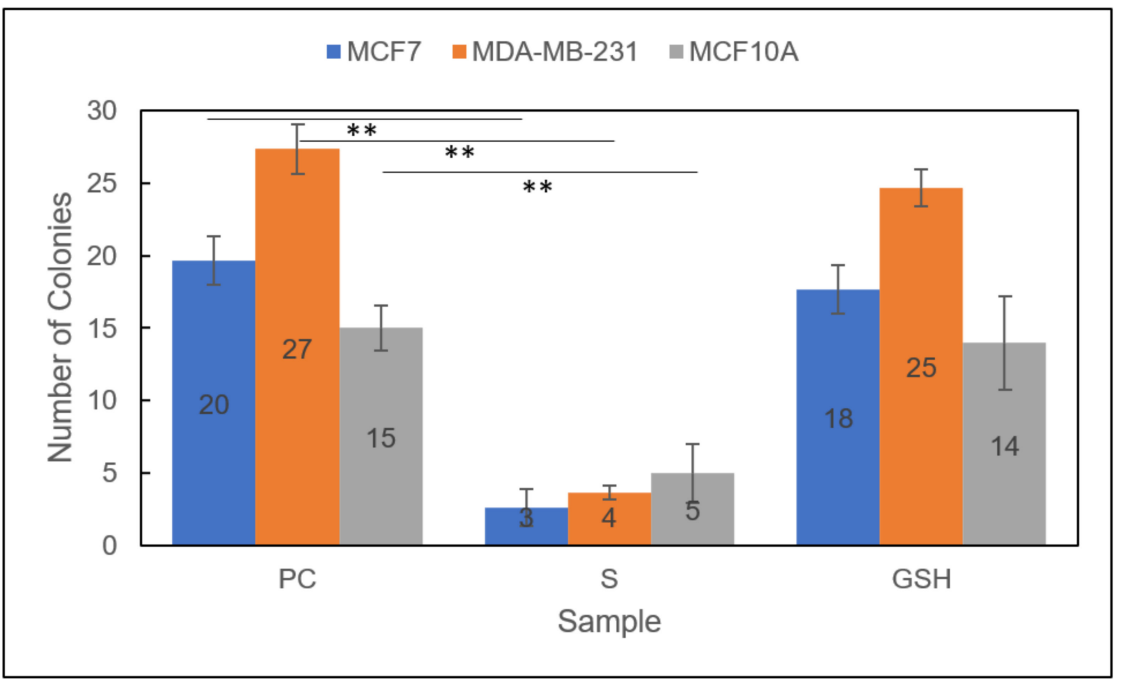

Figure 6. Colony formation capacity of MCF7 (blue), MDA-MB-231 (orange), and MCF10A (gray) cells. Sample groups include: PC (untreated), S (Group 1), and GSH (functional control) cells. Data points represent the mean \pm standard deviation. Statistical differences from the positive control are shown by ${ }^{* *} p<0.01$.

\section{Group 2}

Promisingly, the colony formation capacity of all treated Group 2 cell lines was further reduced than in either therapeutic individually (Figure 7) [29]. Moreover, the clonogenic capacity of both breast carcinoma lines, MCF7 and MDA-MB-231 cells, was completely diminished to 0 after PC untreated cells formed $58 \pm 1$ and $12 \pm 1$, respectively. Again, the normal MCF10A cell line was also affected, reducing the number of colonies formed from $37 \pm 2$ to $6 \pm 1$. As with Group 1, these results indicated a potential drawback to the conceivable application of the Group 2 combinatorial therapeutic approach. Further studies would help determine the overall efficacy and prospective use of these therapeutic approaches for breast carcinomas.

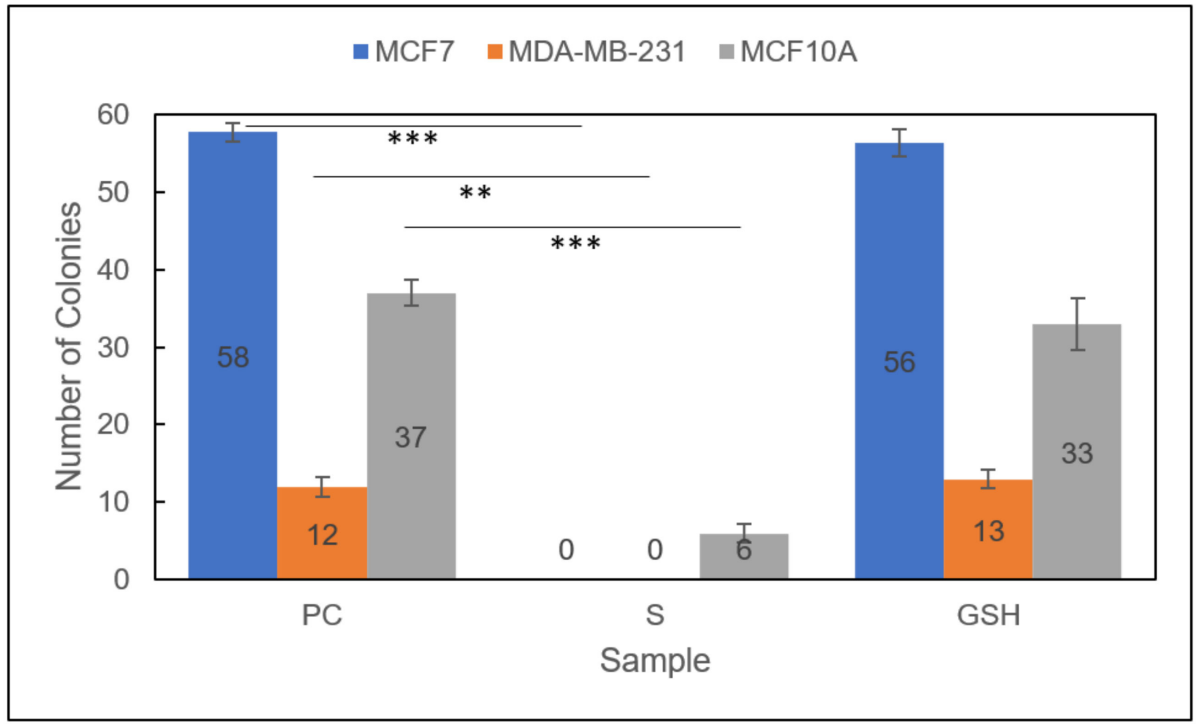

Figure 7. Colony formation capacity of treated Group 2 MCF7 (blue), MDA-MB-231 (orange), and MCF10A (gray) cells. Sample groups include: untreated PC cells, S (Group 2) cells, and GSH-treated cells. Data points represent the mean \pm standard deviation. Statistical differences from the positive control are indicated by ${ }^{* *} p<0.01,{ }^{* * *} p<0.001$. 


\subsection{LIVE/DEAD Assays}

The next method employed to determine therapeutic potential of Group 1 and Group 2 was LIVE/DEAD cytotoxic analysis using fluorescence microscopy. Both breast carcinoma lines, MCF7 and MDA-MB-231 cells, as well as the normal breast cell line, MCF10A, were evaluated and exposed to both treatment groups. In both of the breast carcinoma lines, MCF7 and MDA-MB-231 cells, both treatment groups induced cell death, as shown by the green (dead)-stained cells below. These images also revealed that cell death did occur in MCF10A cells treated by both treatment groups; however, this occurred to a lesser extent than in the breast carcinoma cell lines. Collectively, these images further support the cellular viability and colony formation data analyzed above, highlighting the potential potency and discriminatory capability of the combination treatment approach (Group 2) on breast carcinomas.

Group 1

Optimistically, the LIVE/DEAD fluorescence microscopic analysis revealed that both breast carcinoma cell lines, MCF 7 and MDA-MB-231 cells, were significantly more impacted by Group 1 than normal MCF10A breast cells. This can be seen in the middle images in (Figure 8), where there is obviously more green (dead) staining in the top two images (MCF7 and MDA-MB-231 cells) than the bottom image (MCF10A). The untreated PC images and the GSH-treated images show almost exclusively blue (live) staining. These results encouraged further exploration of cell apoptosis to thoroughly investigate various facets of therapeutic efficacy.

a

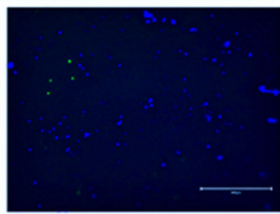

MCF7_PC

b

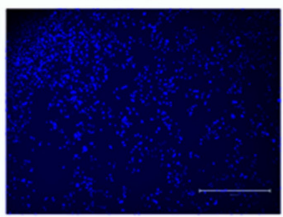

MDA-MB-23I_PC

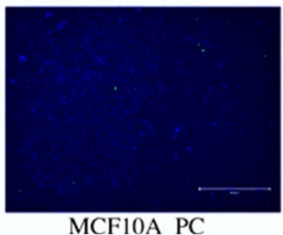

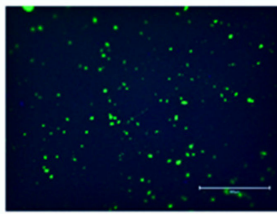

MCF7 GSNO

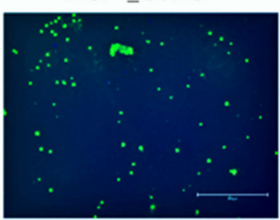

MDA-MB-231_GSNO

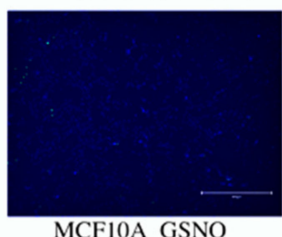

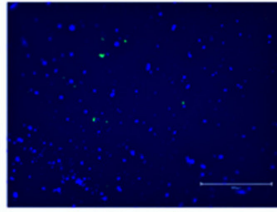

MCF7_GSH

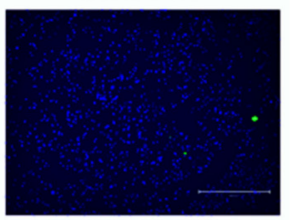

MDA-MB-231_GSH

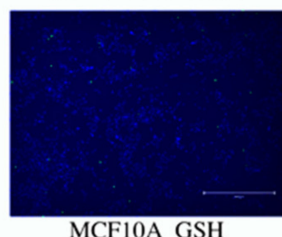

Figure 8. Live/dead cytotoxicity images for NO (Group 1) exposed MCF7 (a) and MDA-MB-231 (b) breast carcinoma cell lines as well as the normal breast cell line MCF10A (c). Images were captured using fluorescence microscopy. Live cells exhibited blue fluorescence and dead cells exhibited green fluorescence. For each cell line, the images on the left-hand side represent untreated PC cells, the images in the middle represent the $S$ (Group 1) cells, and the images on the far right represent GSH-treated cells.

Group 2

Encouragingly, the LIVE/DEAD fluorescence microscopic analysis of Group 2 MCF7, MDA-MB-231, and MCF10A cells also reiterated the cell viability and colony formation results from above (Figure 9). Significantly more dead (green) cells are visible in the breast carcinoma lines, MCF7 and MDA-MB-231 cells, than in the normal breast cell line, MCF10A. Additionally, it is not obvious whether there are significant differences between these images and those of the cells exposed to Group 1 (Figure 8). Similarly, these results prompted further exploration of cell apoptosis. 
a

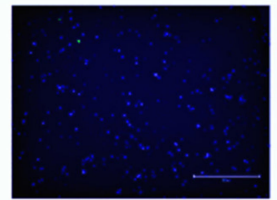

MCF7_PC

b

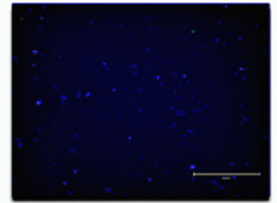

MDA-MB-231_PC

c

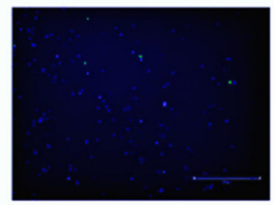

MCF10A PC

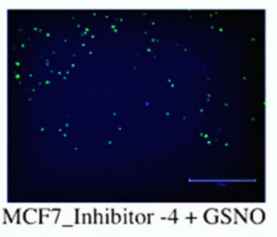

MCF7_Inhibitor -4 + GSNO

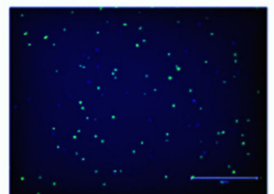

MDA-MB-231_Inhibitor -4 + GSNO

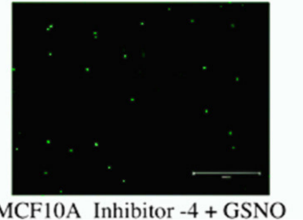

Figure 9. Live/dead cytotoxicity images for Group 2 MCF7 (a) and MDA-MB-231 (b) breast carcinoma cell lines as well as the normal breast cell line MCF10A (c). Images were captured using fluorescence microscopy. Live cells exhibited blue fluorescence while dead cells exhibited green fluorescence. For each cell line, the images on the left side represent untreated PC cells and the images on the right represent the $S$ cells (Group 2).

\subsection{Cell Apoptosis Assays}

\subsubsection{Caspase-Glo 3/7 Apoptosis Assay}

Finally, the last major indicator of therapeutic efficacy assessed in this work was the evaluation of cell apoptosis. The impact of both treatment groups, Group 1 and Group 2, was assessed for the induction of cell apoptosis of MCF7 and MDA-MB-231 breast carcinoma cell lines, as well as normal breast cell line, MCF10A. Two different methods were employed, including a Caspase-Glo 3/7 Assay, to probe for caspase 3/7-mediated induction of apoptosis and Annexin V/FITC and PI staining to display early/late apoptosis and necrosis. Overall, the results showed that Group 2 showed a significantly higher amount of cellular apoptosis in the breast carcinoma cell lines MCF7 (seen via Annexin V/FITC and PI staining) and MDA-MB-231 (seen via increased Caspase 3/7 activity and Annexin V/FITC and PI staining). Annexin V/FITC and PI staining revealed only a very slight increase in apoptosis in the normal MCF10A line. These results support and further reinforce the data collected above, emphasizing the promising potential for this combination therapeutic approach (Group 2) in breast carcinomas.

Group 1

Caspase 3/7 activation was probed for all three cell lines, MCF7, MDA-MB-231, and MCF10A, using the Caspase-Glo 3/7 assay with luminescence detection for Group 1 (Figure 10). Caspase activity was increased slightly for one breast carcinoma line, MDAMB-231, from $1 \pm 0.03$ for untreated PC cells to $1.16 \pm 0.06$ for $S$ (Group 1) cells. Caspase $3 / 7$ activity was not increased for the MCF7 breast carcinoma line. These results make sense because MDA-MB-231 cells are known to experience caspase-mediated induction of apoptosis, while MCF7 cells are known to experience apoptosis without caspase activation [33-35]. The normal MCF10A line also did not experience an increase in caspase $3 / 7$ activity. This makes sense if very little apoptosis occurred. Thus, the results identified $\mathrm{NO}$ (Group 1) as a cytotoxic agent in MDA-MB-231 cells. 


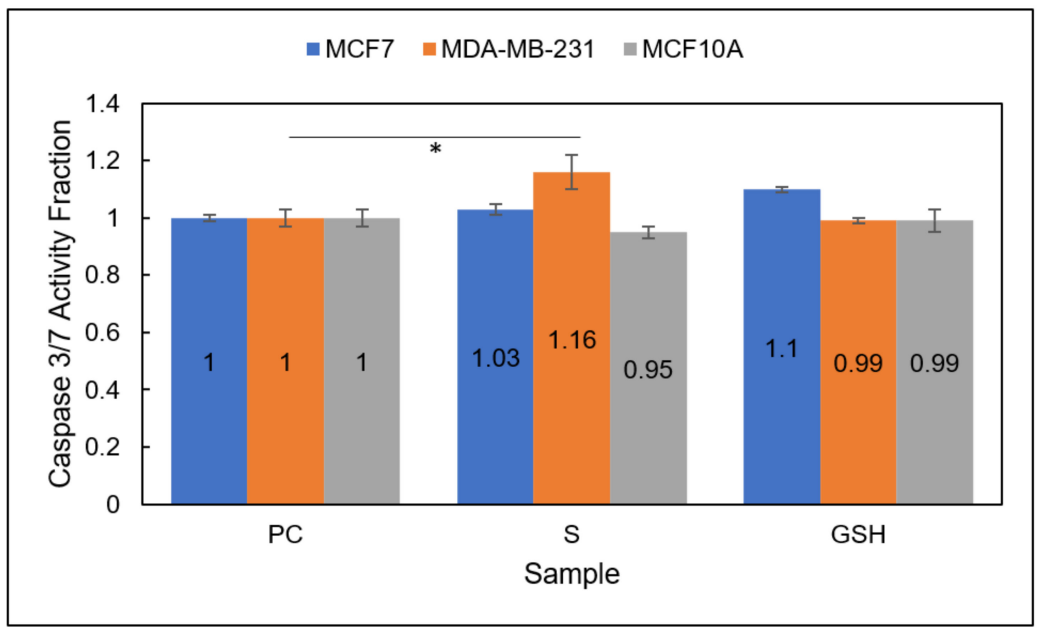

Figure 10. Caspase 3/7 activity fraction of NO (Group 1)-treated MCF7 (blue), MDA-MB-231 (orange), and MCF10A (gray) cells. Sample groups include: untreated PC cells, S (Group 1) cells, and GSHtreated cells. Data points represent the mean \pm standard deviation. Statistically different values from the control are represented by * $p<0.05$.

Group 2

Caspase $3 / 7$ activation was also evaluated for all three cell lines, MCF7, MDA-MB-231, and MCF10A, using the Caspase-Glo 3/7 assay with luminescence detection for Group 2 (Figure 11). Again, the only cell line to experience a change in caspase $3 / 7$ activity was the breast carcinoma line, MDA-MB-231. Notably, the increase in caspase 3/7 activity was much more pronounced than when exposed to NO (Group 1) or inhibitor-4 alone [29]. After Group 2 MDA-MB-231 cells were treated, caspase 3/7 activity of treated cells was $1.57 \pm 0.1$ compared to untreated PC cells at $1 \pm 0.03$. Neither of the other two lines-the MCF7 breast carcinoma line and the normal cell line MCF10A—experienced a statistical change in caspase $3 / 7$ activity. As previously mentioned, this makes sense because MCF7 and MCF10A cells experience caspase-independent apoptosis while MDA-MB-231 cells experience caspase-dependent apoptosis. These results emphasized the combinatorial treatment approach (Group 2) as a more potent apoptosis-inducing agent on MDA-MB-231 breast carcinomas than NO (Group 1)- or inhibitor-4 treated cells.

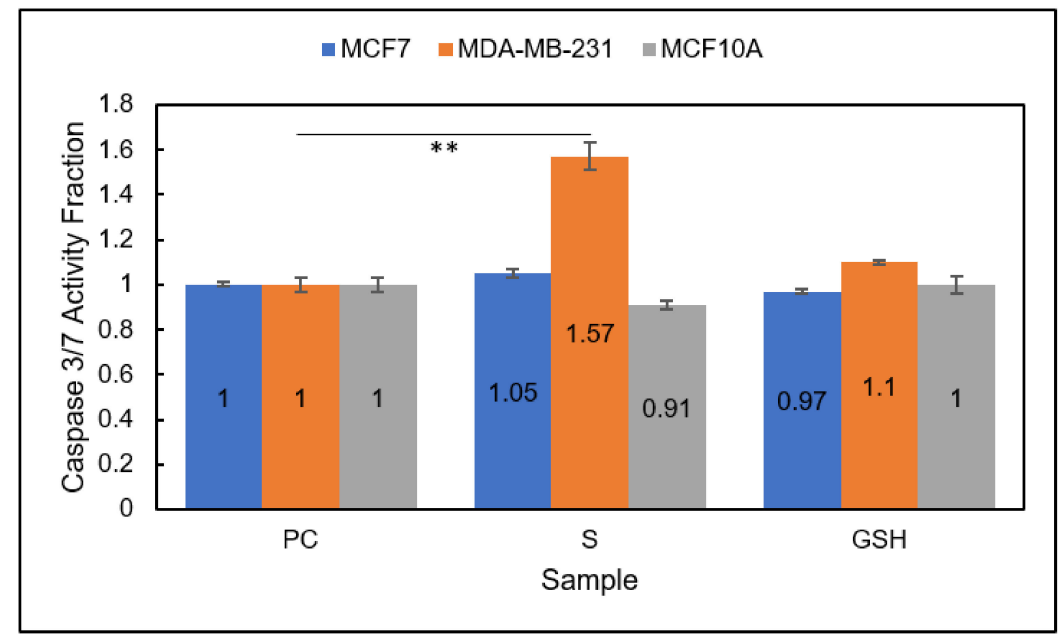

Figure 11. Caspase $3 / 7$ activity fraction of MCF7 (blue), MDA-MB-231 (orange), and MCF10A (gray) cells detected using the Caspase-Glo 3/7 Assay. Sample groups include: untreated PC cells, $\mathrm{S}$ (Group 2) and GSH-treated cells. Data points represent the mean \pm standard deviation. Statistically different values from the control are indicated by ${ }^{* *} p<0.01$. 


\subsubsection{Annexin V/PI Apoptosis Assay}

The second method employed to evaluate apoptosis and the final method to determine overall efficacy in NO (Group 1) and the combination therapeutic (Group 2) was Annexin V-FITC and PI staining with fluorescence microscopy. These data showed the occurrence of apoptosis (early or late stage) as well as necrosis in each sample group (PC, S, GSH) for all three cell lines, MCF7, MDA-MB-231, and MCF10A. Untreated PC cells and GSHtreated cells for all three did not show anything of note, so only the images of $S$ cells are included below (Figures 12 and 13). Overall, each treatment (Group 1 and Group 2) induced significant apoptosis and some necrosis in each of the two breast carcinoma lines, MCF7 and MDA-MB-231 cells. Only a very small amount of fluorescence corresponding to apoptosis was observed in MCF10A cells. These exciting results further reinforced the promising potential of NO (Group 1) and NO + inhibitor-4 combinations (Group 2) in breast carcinoma treatment.

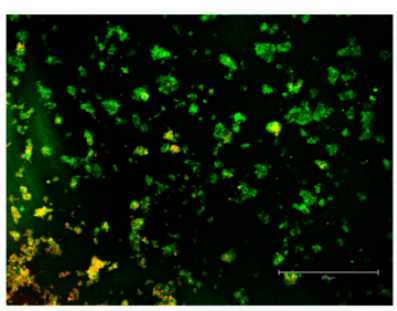

MCF7_GSNO

a

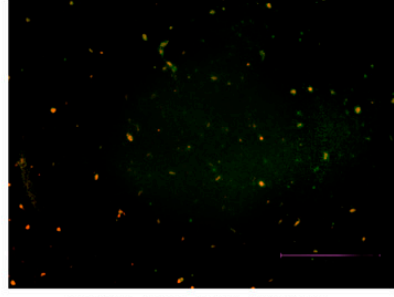

MDA-MB-231_GSNO

$\mathrm{b}$

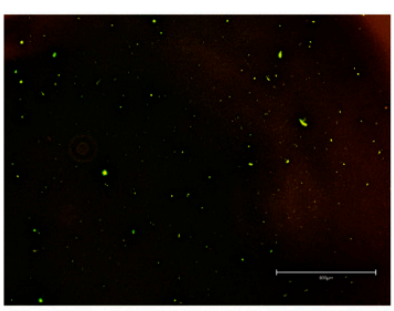

MCF10A_GSNO

$\mathrm{C}$

Figure 12. Detection of apoptosis in MCF7 (a), MDA-MB-231 (b), and MCF10A (c) cells by Annexin V/FITC and PI staining. Cells were treated with NO (Group 1) for $24 \mathrm{~h}$, stained with Annexin V/FITC (green) and PI (red), and then imaged with fluorescence microscopy.

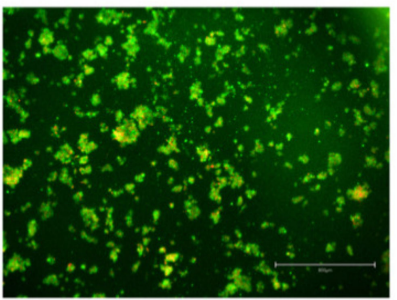

MCF7_Inhibitor -4 + GSNO

a

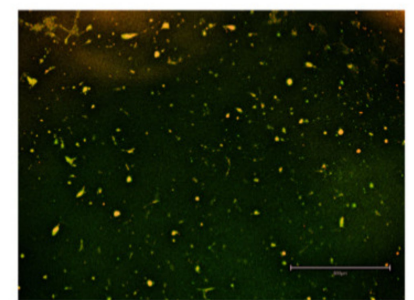

MDA-MB-231_ Inhibitor -4 + GSNO b

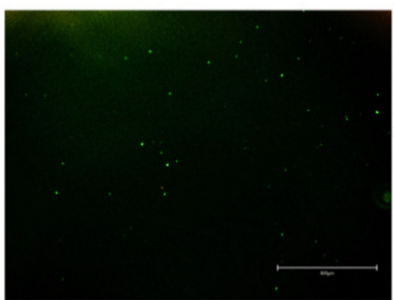

MCF10A_Inhibitor -4 + GSNO

C

Figure 13. Detection of apoptosis in MCF7 (a), MDA-MB-231 (b), and MCF10A (c) cells by Annexin V/FITC and PI staining. Cells were treated with the combination therapeutic (Group 2), then stained with Annexin V/FITC (green) and PI (red) and imaged with fluorescence microscopy.

Group 1

Apoptosis of NO (Group 1)-treated MCF7, MDA-MB-231, and MCF10A cells was analyzed using Annexin V-FITC and PI staining to observe early (Annexin V-FITC only, green) or late-stage apoptosis (both Annexin V-FITC and PI, green and red) as well as necrosis (PI only, red) (Figure 12). Obviously, both MCF7 and MDA-MB-231 breast cancer lines exhibit much more fluorescence, indicating a higher amount of apoptosis than normal MCF10A cells. Additionally, MCF7 cells mostly experienced early apoptosis while MDAMB-231 cells mostly entered late apoptosis. These results identify Group 1 as an apoptosisinducing agent in MCF7 and MDA-MB-231 cells. 


\section{Group 2}

Similarly, MCF7, MDA-MB-231, and MCF10A cells consecutively exposed to the combination therapeutic (Group 2), were analyzed for apoptosis using Annexin V-FITC and PI staining (Figure 13). Again, early apoptosis (Annexin V-FITC only, green), late apoptosis (both Annexin V-FITC and PI, green and red), and necrosis (PI only, red) were observed for each line. Treated MCF7 and MDA-MB-231 breast carcinoma cells displayed significant fluorescence, indicating significant apoptosis in each line. Normal MCF10A cells displayed a very small amount of green fluorescence, indicating a small amount of early stage apoptosis. These results show that the combination treatment approach (Group 2) is a more potent treatment option than NO (Group 1) or inhibitor-4 alone. [29] Ultimately, Group 2 is highly efficacious in cell-line-based breast carcinoma research and deserves continued investigation.

\section{Conclusions}

Ultimately, these results highlight the Group 2 combination therapeutic, $\mathrm{NO}$ (from GSNO) + SMYD-3 inhibition (from inhibitor-4) as an extremely promising treatment for continued application in breast carcinoma treatment. In particular, this treatment shows discriminatory potential to breast carcinomas while imparting very few negative effects on normal breast cells. Future studies of both NO and NO combinations with SMYD-3 inhibition on breast cancers are necessary to determine their efficacy in clinical applications, such as 3D cell culture platforms and animal models.

Supplementary Materials: The following are available online at https:/ / www.mdpi.com/article/ 10.3390/diseases9040082/s1, Excel File 1: Apoptosis, Excel File 2: CF Results, Excel File 3: Viability Data.

Author Contributions: The original draft of this manuscript was prepared by J.L.G. with contribution from K.J.H.; J.L.G. and K.J.H. performed cell-based analyses; J.L.G. analyzed data; J.L.G., K.J.H., M.A.B. and M.M.R. contributed to the review and editing of this manuscript. All authors have read and agreed to the published version of the manuscript.

Funding: This research was supported by Colorado State University Chemistry department.

Institutional Review Board Statement: Not applicable.

Informed Consent Statement: Not applicable.

Data Availability Statement: The data presented in this study is available within the article and supplementary materials.

Acknowledgments: We would like to thank Colorado State University Department of Chemistry for their support.

Conflicts of Interest: This author declares no conflicts of interest.

\section{References}

1. U.S. Cancer Statistics Working Group. U.S. Cancer Statistics Data Visualizations Tool: Based on 2019 Submission Data (1999-2017): U.S. Department of Health and Human Services, Centers for Disease Control and Prevention and National Cancer Institute. Available online: www.cdc.gov/cancer/uscs/dataviz/index.htm (accessed on 19 June 2021).

2. Waks, A.G.; Winer, E.P. Breast Cancer Treatment: A Review. JAMA J. Am. Med. Assoc. 2019, 321, 288-300. [CrossRef] [PubMed]

3. Verma, A.; Kaur, J.; Mehta, K. Molecular oncology update: Breast cancer gene expression profiling. Asian J. Oncol. 2015, 1, 65-72. [CrossRef]

4. Hammond, M.E.H.; Hayes, D.F.; Dowsett, M.; Allred, D.C.; Hagerty, K.L.; Badve, S.; Fitzgibbons, P.L.; Francis, G.; Goldstein, N.S.; Hayes, M.; et al. American society of clinical oncology/college of american pathologists guideline recommendations for immunohistochemical testing of estrogen and progesterone receptors in breast cancer. J. Clin. Oncol. 2010, 28, $2784-2795$. [CrossRef] [PubMed]

5. Smith, I.; Procter, M.; Gelber, R.D.; Guillaume, S.; Feyereislova, A.; Dowsett, M.; Goldhirsch, A.; Untch, M.; Mariani, G.; Baselga, J.; et al. 2-year follow-up of trastuzumab after adjuvant chemotherapy in HER2-positive breast cancer: A randomised controlled trial. Lancet 2007, 369, 29-36. [CrossRef] 
6. Gianni, L.; Dafni, U.; Gelber, R.D.; Azambuja, E.; Muehlbauer, S.; Goldhirsch, A.; Untch, M.; Smith, I.; Baselga, J.; Jackisch, C.; et al. Treatment with trastuzumab for 1 year after adjuvant chemotherapy in patients with HER2-positive early breast cancer: A 4-year follow-up of a randomised controlled trial. Lancet Oncol. 2011, 12, 236-244. [CrossRef]

7. Denkert, C.; Liedtke, C.; Tutt, A.; von Minckwitz, G. Molecular alterations in triple-negative breast cancer-The road to new treatment strategies. Lancet 2017, 389, 2430-2442. [CrossRef]

8. Foulkes, W.D.; Smith, I.E.; Reis-filho, J.S. Triple-Negative Breast Cancer. N. Engl. J Med. 2010, 363, 1938-1948. [CrossRef]

9. Howlader, N.; Altekruse, S.F.; Li, C.I.; Chen, V.W.; Clarke, C.A.; Ries, L.A.G.; Cronin, K.A. US incidence of breast cancer subtypes defined by joint hormone receptor and HER2 status. J. Natl. Cancer Inst. 2014, 106. [CrossRef]

10. Thomsen, L.; Miles, D.; Happerfield, L.; Bobrow, L.; Knowles, R.; Monacada, S. Nitric oxide synthase activity in human breast cancer. Br. J. Cancer 1995, 72, 41-44. [CrossRef]

11. Pervin, S.; Singh, R.; Chaudhuri, G. Nitric oxide, Nw-hydroxy-l-arginine and breast cancer. Nitric Oxide Biol. Chem. 2008, 19, 103-106. [CrossRef]

12. Pervin, S.; Singh, R.; Chaudhuri, G. Nitric oxide-induced cytostasis and cell cycle arrest of a human breast cancer cell line (MDA-MB-231): Potential role of cyclin D1. Proc. Natl. Acad. Sci. USA 2001, 98, 3583-3588. [CrossRef] [PubMed]

13. Pervin, S.; Singh, R.; Freije, W.A.; Chaudhuri, G. MKP-1-Induced Dephosphorylation of Extracellular Signal-Regulated Kinase Is Essential for Triggering Nitric Oxide-Induced Apoptosis in Human Breast Cancer Cell Lines: Implications in Breast Cancer. Cancer Res. 2003, 63, 8853-8860.

14. Pervin, S.; Singh, R.; Chaudhuri, G. Nitric-oxide-induced Bax integration into the mitochondrial membrane commits MDA-MB468 cells to apoptosis: Essential role of Akt. Cancer Res. 2003, 63, 5470-5479.

15. Pervin, S.; Singh, R.; Hernandez, E.; Wu, G.; Chaudhuri, G. Nitric oxide in physiologic concentrations targets the translational machinery to increase the proliferation of human breast cancer cells: Involvement of mammalian target of rapamycin/eIF4E pathway. Cancer Res. 2007, 67, 289-299. [CrossRef] [PubMed]

16. Findlay, V.J.; Townsend, D.M.; Saavedra, J.E.; Buzard, G.S.; Citro, M.L.; Keefer, L.K.; Ji, X.; Tew, K.D. Tumor cell responses to a novel glutathione S-transferase-activated nitric oxide-releasing prodrug. Mol. Pharmacol. 2004, 65, 1070-1079. [CrossRef]

17. Hou, Y.; Wang, J.; Andreana, P.R.; Cantauria, G.; Tarasia, S.; Sharp, L.; Braunschweiger, P.G.; Wang, P.G. Targeting nitric oxide to cancer cells: Cytotoxicity studies of glyco-S-nitrosothiols. Bioorg. Med. Chem. Lett. 1999, 9, 2255-2258. [CrossRef]

18. Suchyta, D.J.; Schoenfisch, M.H. Encapsulation of N-diazeniumdiolates within liposomes for enhanced nitric oxide donor stability and delivery. Mol. Pharm. 2015, 12, 3569-3574. [CrossRef] [PubMed]

19. Suchyta, D.J.; Schoenfisch, M.H. Anticancer potency of nitric oxide-releasing liposomes. RSC Adv. 2017, 7, 53236-53246. [CrossRef]

20. Dong, R.; Wang, X.; Wang, H.; Liu, Z.; Liu, J.; Saavedra, J.E. Effects of JS-K, a novel anti-cancer nitric oxide prodrug, on gene expression in human hepatoma Hep3B cells. Biomed. Pharmacother. 2017, 88, 367-373. [CrossRef]

21. Reynolds, M.M.; Witzeling, S.D.; Damodaran, V.B.; Medeiros, T.N.; Knodle, R.D.; Edwards, M.A.; Lookian, P.P.; Brown, M.A. Applications for nitric oxide in halting proliferation of tumor cells. Biochem. Biophys. Res. Commun. 2013, 431, 647-651. [CrossRef]

22. Kogias, E.; Osterberg, N.; Baumer, B.; Psarras, N.; Koentges, C.; Papazoglou, A.; Saavedra, J.E.; Keefer, L.K.; Weyerbrock, A. Growth-inhibitory and chemosensitizing effects of the glutathione-S-transferase- $\pi$-activated nitric oxide donor PABA/NO in malignant gliomas. Int. J. Cancer 2012, 130, 1184-1194. [CrossRef]

23. Hamamoto, R.; Furukawa, Y.; Morita, M.; Iimura, Y.; Silva, F.P.; Li, M.; Yagyu, R.; Nakamura, Y. SMYD3 encodes a histone methyltransferase involved in the proliferation of cancer cells. Nat. Cell Biol. 2004, 6, 731-740. [CrossRef]

24. Brown, M.A.; Foreman, K.; Harriss, J.; Das, C.; Zhu, L.; Edwards, M.; Shaaban, S.; Tucker, H. C-terminal domain of SMYD3 serves as a unique HSP90-regulated motif in oncogenesis. Oncotarget 2015, 6, 4005-4019. [CrossRef]

25. Komatsu, S.; Imoto, I.; Tsuda, H.; Kozaki, K.I.; Muramatsu, T.; Shimada, Y.; Aiko, S.; Yoshizumi, Y.; Ichikawa, D.; Otsuji, E.; et al. Overexpression of SMYD2 relates to tumor cell proliferation and malignant outcome of esophageal squamous cell carcinoma. Carcinogenesis 2009, 30, 1139-1146. [CrossRef]

26. Cock-Rada, A.M.; Medjkane, S.; Janski, N.; Yousfi, N.; Perichon, M.; Chaussepied, M.; Chluba, J.; Langsley, G.; Weitzman, J.B. SMYD3 promotes cancer invasion by epigenetic upregulation of the metalloproteinase MMP-9. Cancer Res. 2012, 72, 810-820. [CrossRef]

27. Luo, X.G.; Zhang, C.L.; Zhao, W.W.; Liu, Z.P.; Liu, L.; Mu, A.; Guo, S.; Wang, N.; Zhou, H.; Zhang, T.C. Histone methyltransferase SMYD3 promotes MRTF-A-mediated transactivation of MYL9 and migration of MCF-7 breast cancer cells. Cancer Lett. 2014, 344, 129-137. [CrossRef]

28. Hamamoto, R.; Silva, F.P.; Tsuge, M.; Nishidate, T.; Katagiri, T.; Nakamura, Y.; Furukawa, Y. Enhanced SMYD3 expression is essential for the growth of breast cancer cells. Cancer Sci. 2006, 97, 113-118. [CrossRef]

29. Alshiraihi, I.M.; Jarrell, D.K.; Arhouma, Z.; Hassell, K.N.; Montgomery, J.; Padilla, A.; Ibrahim, H.M.; Crans, D.C.; Kato, T.A.; Brown, M.A. In silico/in vitro hit-to-lead methodology yields smyd3 inhibitor that eliminates unrestrained proliferation of breast carcinoma cells. Int. J. Mol. Sci. 2020, 21, 9549. [CrossRef]

30. Gordon, J.L.; Reynolds, M.M.; Brown, M.A. Nitric Oxide as a Potential Adjuvant Therapeutic for Neuroblastoma: Effects of NO on Murine N2a Cells. Vet. Sci. 2020, 7, 51. [CrossRef]

31. Gordon, J.L.; Hinsen, K.J.; Reynolds, M.M.; Smith, T.A.; Tucker, H.O.; Brown, M.A. Anticancer potential of nitric oxide (NO) in neuroblastoma treatment. RSC Adv. 2021, 11, 9112-9120. [CrossRef] 
32. Zhang, Y.; Sun, C.; Xiao, G.; Shan, H.; Tang, L.; Yi, Y.; Yu, W.; Gu, Y. S-nitrosylation of the Peroxiredoxin-2 promotes Snitrosoglutathione-mediated lung cancer cells apoptosis via AMPK-SIRT1 pathway. Cell Death Dis. 2019, 10. [CrossRef] [PubMed]

33. Lai, P.E.I.C.; Chiu, T.E.D.H.; Huang, Y.E.N.T.A. Overexpression of BDNF and TrkB in human. Anticancer Res. 2010, 31, 1265-1270. [CrossRef]

34. Tor, Y.S.; Yazan, L.S.; Foo, J.B.; Wibowo, A.; Ismail, N.; Cheah, Y.K.; Abdullah, R.; Ismail, M.; Ismail, I.S.; Yeap, S.K. Induction of apoptosis in MCF-7 cells via oxidative stress generation, mitochondria-dependent and caspase-independent pathway by ethyl acetate extract of Dillenia suffruticosa and its chemical profile. PLoS ONE 2015, 10, e0127441. [CrossRef] [PubMed]

35. Pozo-Guisado, E.; Merino, J.M.; Mulero-Navarro, S.; Lorenzo-Benayas, M.J.; Centeno, F.; Alvarez-Barrientos, A.; Fernandez Salguero, P.M. Resveratrol-induced apoptosis in MCF-7 human breast cancer cells involves a caspase-independent mechanism with downregulation of Bcl-2 and NF-kB. Int. J. Cancer 2005, 115, 74-84. [CrossRef] 